\begin{tabular}{|c|c|c|}
\hline \hline & \begin{tabular}{c} 
International Journal of Current Research in \\
Biosciences and Plant Biology \\
\hline EXCELLENT \\
PUBLISHERS
\end{tabular} & Volume $4 \bullet$ Number 6 (June-2017) ・ ISSN: 2349-8080 (Online) \\
\hline
\end{tabular}

\title{
Histology and Spermatogenesis in Frigate Tuna Auxis thazard (Lacepède, 1800) Caught in Continental Shelf Waters of Côte d'Ivoire
}

\author{
Laurent BAHOU ${ }^{1 *}$, Marie-Anne d'ALMEIDA ${ }^{2}$, Célestin ATSÉ BOUA ${ }^{1}$, Tidiani KONÉ ${ }^{3}$ \\ ${ }^{I}$ Centre de Recherches Océanologiques, 29, Rue des Pêcheurs, Treichville - BP V 18 Abidjan - Fax : (225) 213511 55, \\ Côte d'Ivoire \\ ${ }^{2}$ Laboratoire de Biologie Cellulaire, UFR Biosciences, Université Félix HOUPHOUËT-BOIGNY 22 BP 582 Abidjan 22, \\ Côte d'Ivoire \\ ${ }^{3}$ UFR Environnement, Université Jean Lorougnon GUÉDÉ, BP 150 Daloa, Côte d'Ivoire
}

*Corresponding author.

\begin{abstract}
Changes in the testes of frigate tuna specimens were investigated during a yearly-cycle period, from January to December 2004. Most of the individuals examined ranged in size from 25 to $48 \mathrm{~cm}$ FL (centimetre fork length). The study shows description of the sixmaturity stages of males frigate tuna determined on the basis of the macroscopic observation and histological characteristics regarding reproduction in this small tuna. Males investigated have lobular testicular structure. These lobules arrange in a branching system of tubules, from the inner toward the outermost side at the testicular periphery, enabling the germ cells to develop within such a structure.
\end{abstract}

\section{Article Info}

Accepted: 16 May 2017

Available Online: 06 June 2017

\section{Keywords}

Frigate tuna

Gametes

Maturity stages

Spermatogenesis

Tubules

\section{Introduction}

Auxis thazard is one of the two species [Auxis thazard (Lacepède, 1800) and Auxis rochei (Risso, 1810)] known to date as belonging to the genus Auxis. Frigate tuna are pelagic fish that range over most of the world's seas, including tropical and subtropical seas as well as the Mediterranean and Black Seas (Collette and Nauen, 1983). Their body is counter-shaded with darker colour dorsally and lighter colour ventrally and laterally (Bahou, 2013). Colouring on head is almost black and the back is blue purple (Jimenez-Prado and Bearez, 2004). This species whose ventral and lateral surfaces are white-coloured with no markings and spots (Collette and Nauen, 1983) can reach up to about $58 \mathrm{~cm}$ as maximum size (FAO, 2012).

While frigate tuna are epipelagic and oceanic, they do come close to shore as neritic fishes (Collette and Nauen, 1983). In Côte d'Ivoire, West Africa, they do have a year-long occurrence over the continental shelf where they are caught in gillnets deployed by an inshore small-scale fishery (Bahou et al., 2007).

Though reproduction involves both the female and male fish, most studies dealing with the histology of 
gonads are being focused on the former, causing sometimes the reproduction in the later to be less documented. This paper deals with the reproduction in male frigate tuna, with an emphasis laid on the histological characteristics.

\section{Materials and methods}

Male frigate tuna were collected weekly from commercial catches taken in coastal waters of the continental shelf of Côte d'Ivoire (Fig. 1). Specimens (n = 369) were caught between January and December 2004. Fishing gears used included numerous gillnets of 25 and $35 \mathrm{~mm}$ mesh joined to each other, making up a single drifting gillnet which can reach up to about 2,0002,500 $\mathrm{m}$ in length (See Bard et al., 2002). Fishing operation is fully described in preceding works (Bahou et al., 2007; Bahou, 2013).

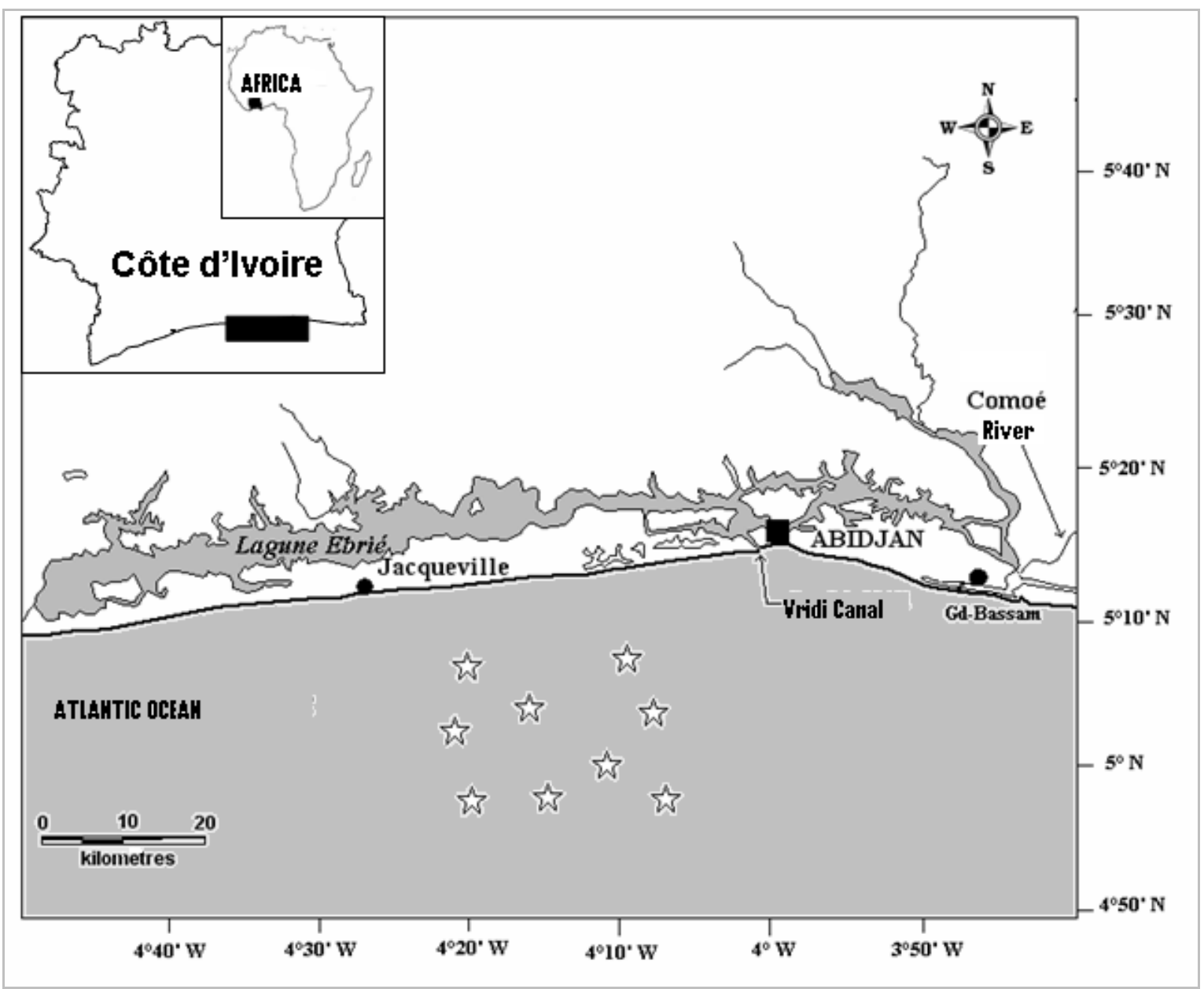

Fig. 1: Map of the fishing area (the centre of the fishing area is approximately $4^{\circ} 80^{\prime} \mathrm{N}-5^{\circ} 10^{\prime} \mathrm{N}$ and $4^{\circ} 30^{\prime} \mathrm{W}$ $-4^{\circ} \mathrm{W}$ ), as indicated in Bahou et al. (2007).

Prior to histological processing, specimens were measured to the nearest centimetre fork length and weighed to the nearest $0.1 \mathrm{~g}$. Photographs were taken of the fish while dissecting them and each individual fish was assigned a maturity stage, following Chur (1972) and Diouf (1980) as enhanced by our own observation of the gonads of dissected specimens. Macroscopic observation comprised criteria regarding the colour, consistency, resistance to pressing, and vascularization of testes. The preparation of micro slides of testes and histological processing were carried out adopting standard histological techniques (See Martoja and Martoja-Pierson, 1967). All testes were preserved in Bouin's fluid, embedded in paraffin, and thin-sectioned at $7 \mu \mathrm{m}$. Staining of slides was carried out with Hematoxylin and Eosin ( $\mathrm{H} \& \mathrm{E})$. The slides were finally mounted in Distrene Platicizal Xylene (DPX) mountant and observed under a light microscope. Photographs of the maturity stages were taken using a digital camera. 


\section{Results}

\section{Length frequency distribution of specimens captured}

Histograms in Fig. 2 show the sizes of frigate tuna
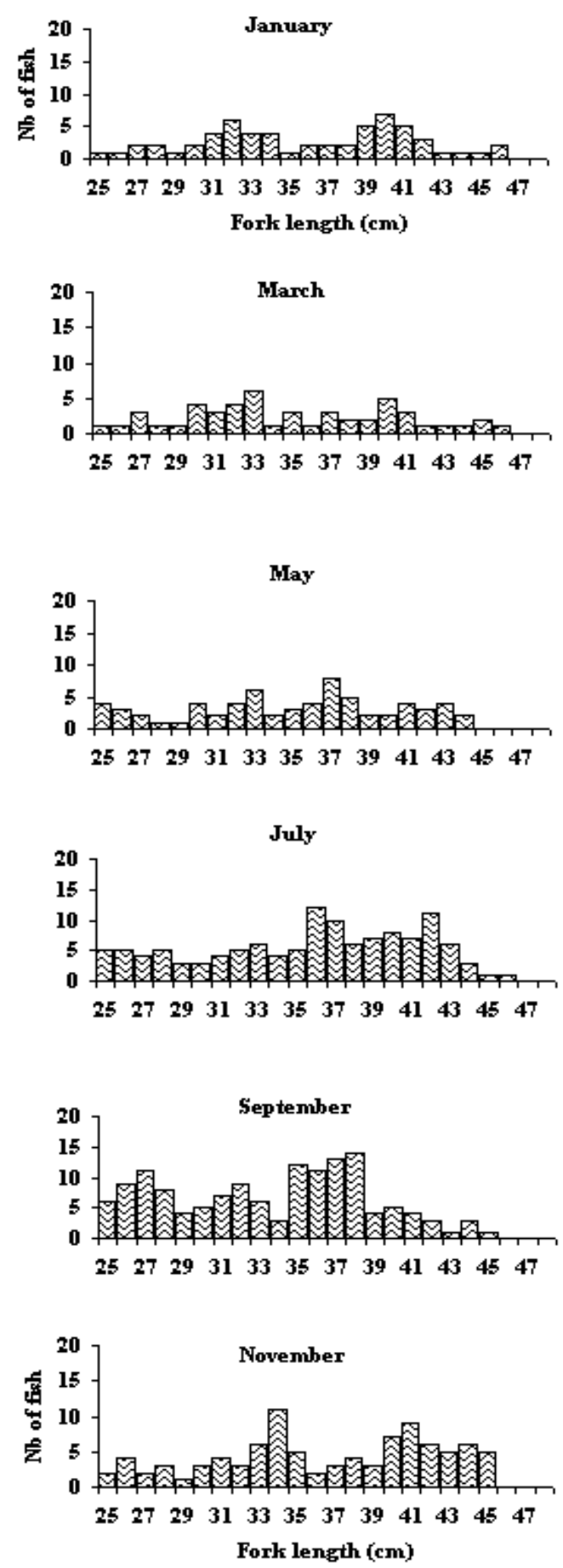

specimens that were frequently caught in the gillnets deployed over the shelf of Côte d'Ivoire by the smallscale fishery. These sizes ranged from 25 to $48 \mathrm{~cm}$ FL, which indicated that immature and adult fishes made up the catches. Variation in modal-size classes can be noted, due to size heterogeneity in the captured fish.
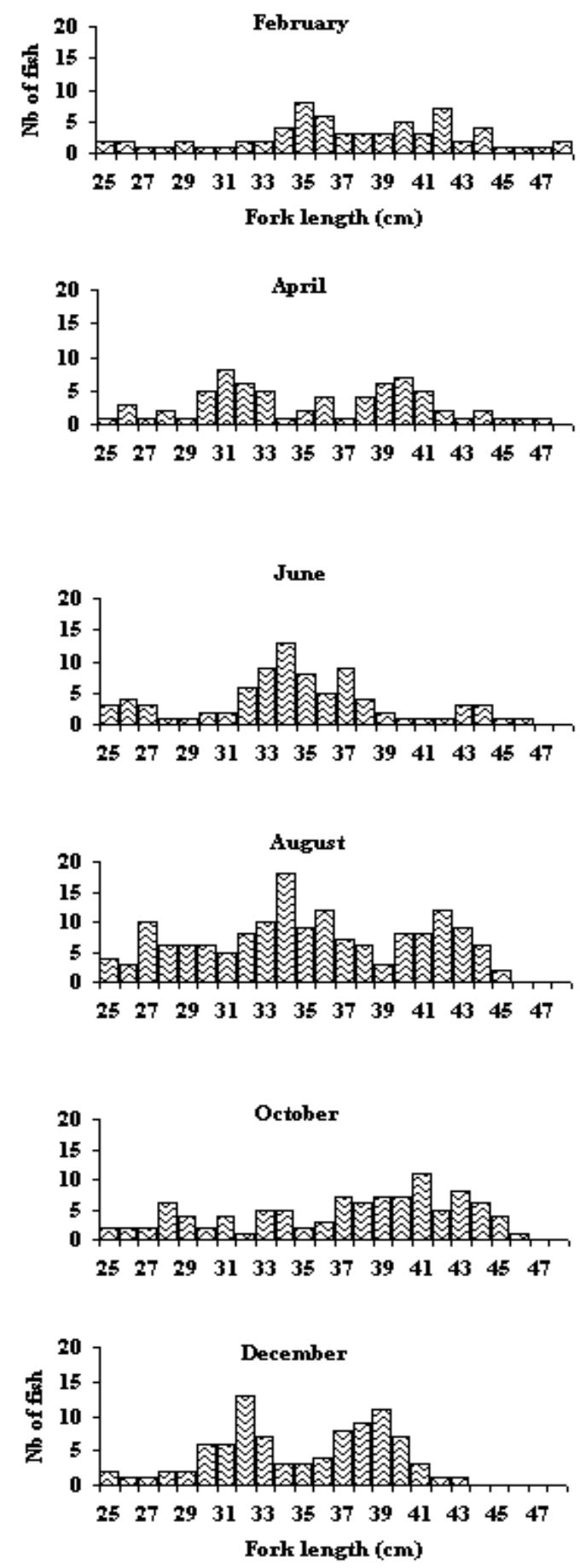

Fig. 2: Length frequency distribution for frigate tuna specimens landed by the small-scale fishery at Abidjan fishing port (Note: males and females have been lamped together). 


\section{Macroscopic and histological descriptions of testes}

Testes' size, the counter-shaded-colouring trends of the outermost and inner sides of testes, the occurrence of lobules or tubules and the size of the main sperm duct, as well as the size of germ cells made up the main criteria we used to identify the six maturity stages in male frigate tuna.

\section{The immature stage I (Fig. 3)}

Testes measured 8.9 to $11.0 \mathrm{~cm}(9.8 \pm 0.5 \mathrm{~cm})$ and weighed up to about 0.10 to $0.24 \mathrm{~g}(0.16 \pm 0.04 \mathrm{~g})$ in specimens of 25 to $29 \mathrm{~cm}$ FL $(26.5 \pm 1.3 \mathrm{~cm} \mathrm{FL})$. They were elongated, almost transparent and recognizable to their shape in thin plate (Fig. 3A). Testes usually stretch singly on the anterior side but are joined to each other in the main sperm duct on the posterior side. They have no blood vessels visible on the surface. Histological observation indicated that in immature phase, the testis is counter-shaded, with a darker side (the cortex) and an inner lighter side (the medulla) (Fig. 3B). Both sides seem to be empty of cells when observed under low magnification.
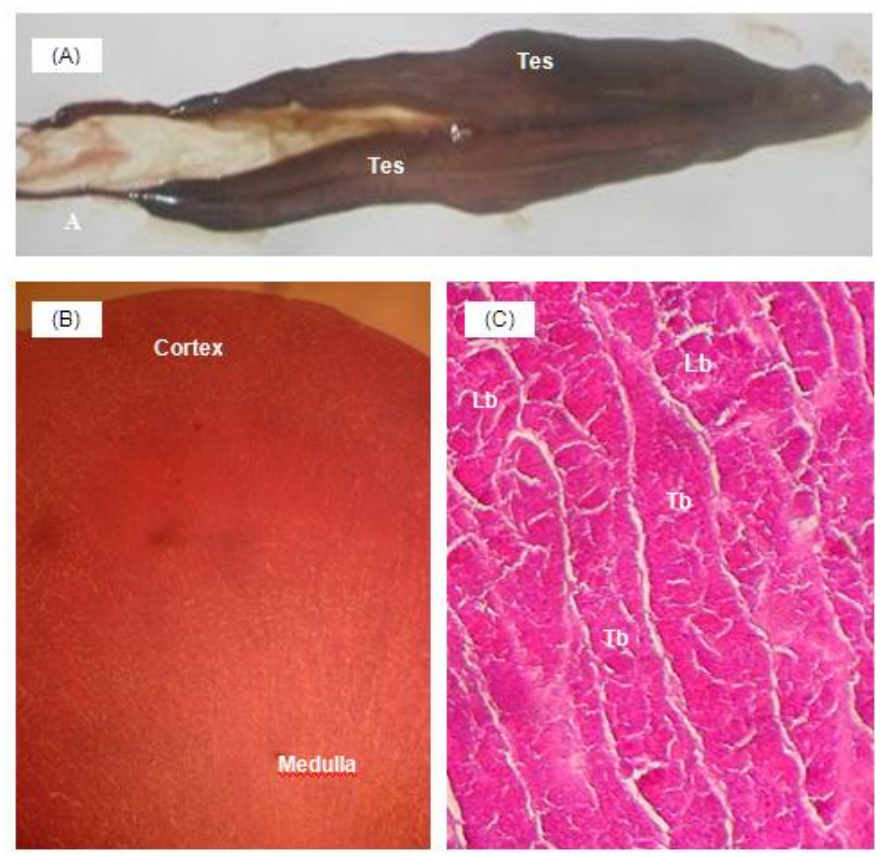

Fig. 3: Testes of an immature Auxis thazard specimen.

(A) Overall appearance of immature testes. (B) Microscopic observation of testes of an immature specimen under low magnification ( $\times 32)$. ( $\mathrm{H} \& \mathrm{E})$. (C) Cross section of immature testes observed under higher magnification $(\times 200)$. $(\mathrm{H} \& \mathrm{E}) \cdot \mathrm{Lb}=$ lobules; $\mathrm{Tb}=$ tubules; Tes $=$ testes.
However, when observed under higher magnification, the medulla shows accumulation of round-like cells, the lobules, arranged one after another as if forming an elongated structure, the tubules (Fig. 3C). The germ cells development known as spermatogenesis undoubtedly occurs within the lobules and tubules.

\section{The onset of maturation or stage II (Fig. 4)}

The ventral side of testes showed a few blood vessels on its surface (Fig. 4A). Testes got bigger than the ones in the preceding stage. They were firm and pinkish in colour. Within the lobules and tubules, germ cells such as spermatogonia and spermatocytes (derived from mitotic and meiotic divisions, respectively), appear to be like dark or purple-coloured dots distributed from the inner toward the transition zone between the medulla and the cortex (Figs. 4B and 4C). In addition, cross sections of testes showed germ cells distribution trend from the cortex to the medulla and their temporary accumulation therein. This step is undoubtedly crucial in the development of spermatids and spermatozoa as a result of the further gametes differentiation process.
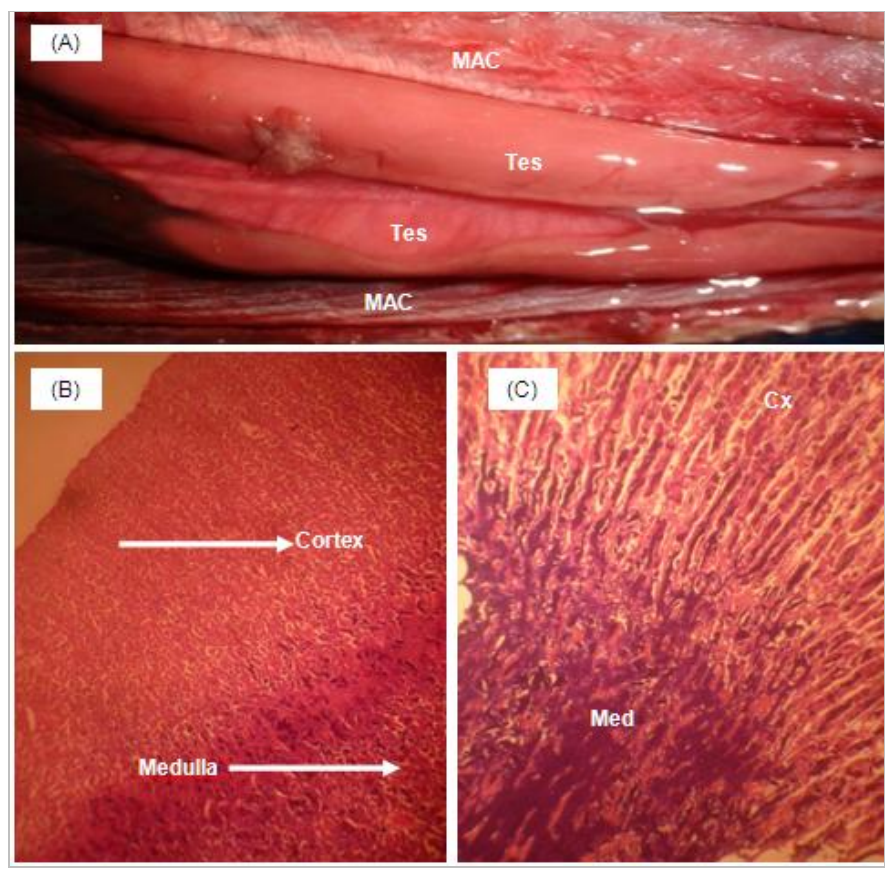

Fig. 4: Testes of an Auxis thazard specimen at stage II.

(A) Overall appearance of testes at onset of maturation. (B) Overall view of the testicular portion (cortex + medulla) of an adult Auxis thazard specimen at stage II. $(\times 32)(\mathrm{H} \& \mathrm{E})$. (C) Cross section of testes of Auxis thazard at stage II observed under higher magnification $(\times 100)$. $(\mathrm{H} \& \mathrm{E}) . \mathrm{Cx}=$ cortex; Med = medulla; MAC $=$ muscles of abdominal cavity; Tes $=$ testes. 


\section{The maturation stage III (Figs. 5 and 6)}

Testes were white in colour, much bigger than the ones in the preceding stage, and got more vascularized ventrally (Fig. 5A). The spermatids (derived from meiotic division of the spermatocytes), visible at the end of the maturation phase, occupy approximately the central part of the lobules (Figs. 5B, 5C, 6A, and 6B). Cross sections of testes showed that there was an increasing trend in germ cells development. These cells, relatively few in number in the transition zone between the medulla and the cortex, got more numerous and distributed within the medulla. Thus, gametes development is centripetal. Additionally, lobules have various shapes and sizes. The progressive germ cells development known as spermatogenesis occurs within the lobules and tubules.

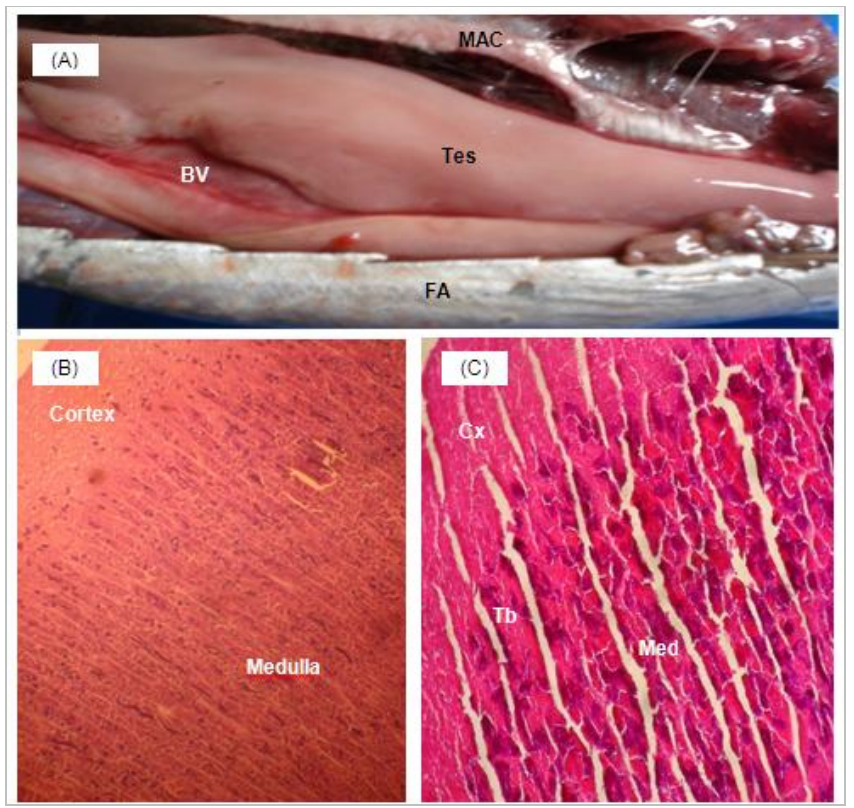

Fig. 5: Testes of an Auxis thazard specimen at stage III (maturation). (A) Overall appearance of testes at maturation stage. (B) Overall observation of the testicular portion of an adult Auxis thazard specimen at stage III $(\times 32)$. (H \& E). (C) Cross section of the testis of an adult Auxis thazard specimen at stage III observed under higher magnification $(\times 200)$. (H \& $\mathrm{E}) . \mathrm{BV}=$ blood vessels; $\mathrm{Cx}=$ cortex; FA = fish abdomen; Med = medulla; MAC $=$ muscles of abdominal cavity; $\mathrm{Tb}=$ tubules; Tes $=$ testes.

The apparent size of the dark dots within the lobules enabled us to distinguish between two cells division stages (Figs. 6A and 6B). Within these lobules, the primary spermatogonia are found in cysts. The cysts are usually found singly near the periphery of the testis. A cyst situated on the lobule wall is shown in Fig. 6B.
Through the spermatogenesis process, the secondary spermatogonia meiotically divide to form spermatocytes. Primary spermatocytes are much bigger than secondary spermatocytes. These spermatocytes then meiotically divide to become spermatids. Spermatids are much smaller, scarcely joined side by side to one another.

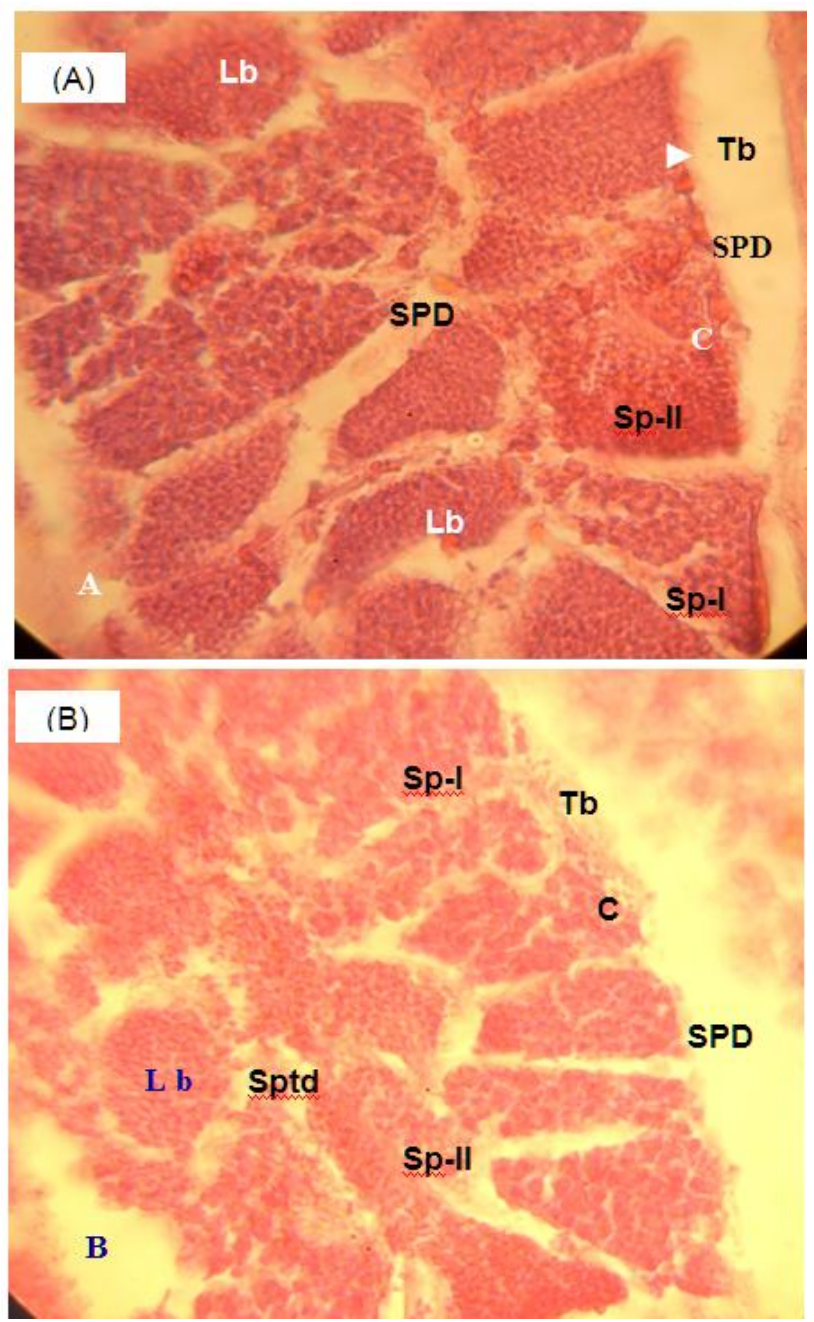

Fig. 6: Cross section of testes showing in details the lobular and testicular arrangements in an adult Auxis thazard specimen at stage III. (A) A less advanced division stage ( $\times$ 1000). ( $\mathrm{H} \& \mathrm{E})$. (B) A more advanced division stage ( $\times 1000) .(\mathrm{H} \& \mathrm{E}) . \mathrm{C}=$ cysts; Lb = lobules; Sp-I = primary spermatocytes; Sp-II = secondary spermatocytes; Sptd = spermatids; $\mathrm{SPD}=$ sperm duct; $\mathrm{Tb}=$ tubules.

\section{The ripening stage IV (Figs. 7 and 8)}

Testes reached maximum size, measuring between 13.0 and $18.1 \mathrm{~cm}(16.0 \pm 1.5 \mathrm{~cm})$ and weighing 20.67 to $46.78 \mathrm{~g}(33.17 \pm 7.81 \mathrm{~g})$ in specimens whose sizes varied between 36 and $46 \mathrm{~cm}$ FL $(39.8 \pm 2.6 \mathrm{~cm} \mathrm{FL})$. 
Testes were almost pinkish in colour, with blood vessels visible on the ventral side (Fig. 7A). On the histological level, we noted that spermatids probably underwent the spermiogenesis process, since the majority of germ cells observed resembled spermatozoa. These spermatozoa mainly accumulated in the main sperm duct, and to a lesser extent, around the lobular lumina (Fig. 7B). Additionally, accumulation of spermatozoa (purple-coloured dots) in the tubules convergence zone (TCZ) was observed. The TCZ is located near the center of the testis (Fig. 7B). In Fig. 7C, we can see white-coloured milt, especially in the anfractuosities of the sperm duct. The main sperm duct is located near the center of the testis as well. It got filled with spermatozoa derived from double meiotic division of spermatids.

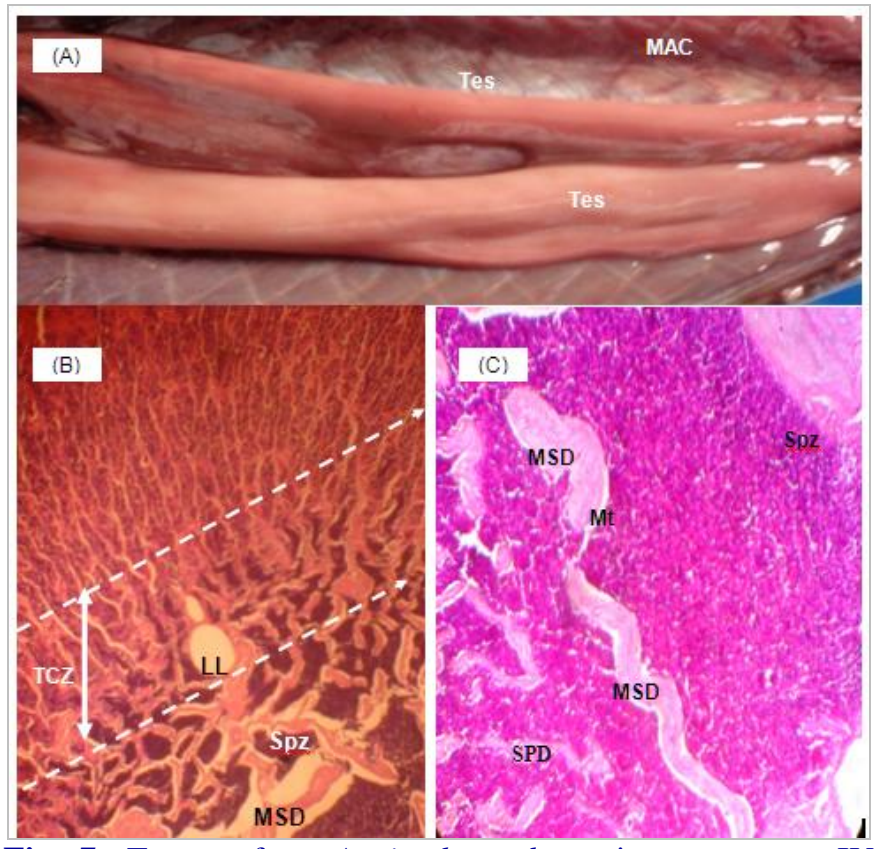

Fig. 7: Testes of an Auxis thazard specimen at stage IV (running male, ripe fish). (A) Overall appearance of testes of a running male specimen. (B) Cross section of the testis of a ripe Auxis thazard specimen ( $\times$ 100). (H \& E). (C) Observation of the medulla of a ripe fish under higher magnification $(\times 200)$. (H \& E). LL = lobular lumina; $\mathrm{Mt}=$ milt; $\mathrm{MAC}=$ muscles of abdominal cavity; $\mathrm{MSD}=$ main sperm duct; SPD = sperm duct; Spz = spermatozoa; Tes = testes; $\mathrm{TCZ}=$ tubules convergence zone.

The apparent size of germ cells, some of which appear to tangle up, indicates the presence of spermatozoa (Figs. 8A, 8B, and 8C). Flagella of these spermatozoa arranged as if showing a combined movement of dense filaments (Fig. 8C).

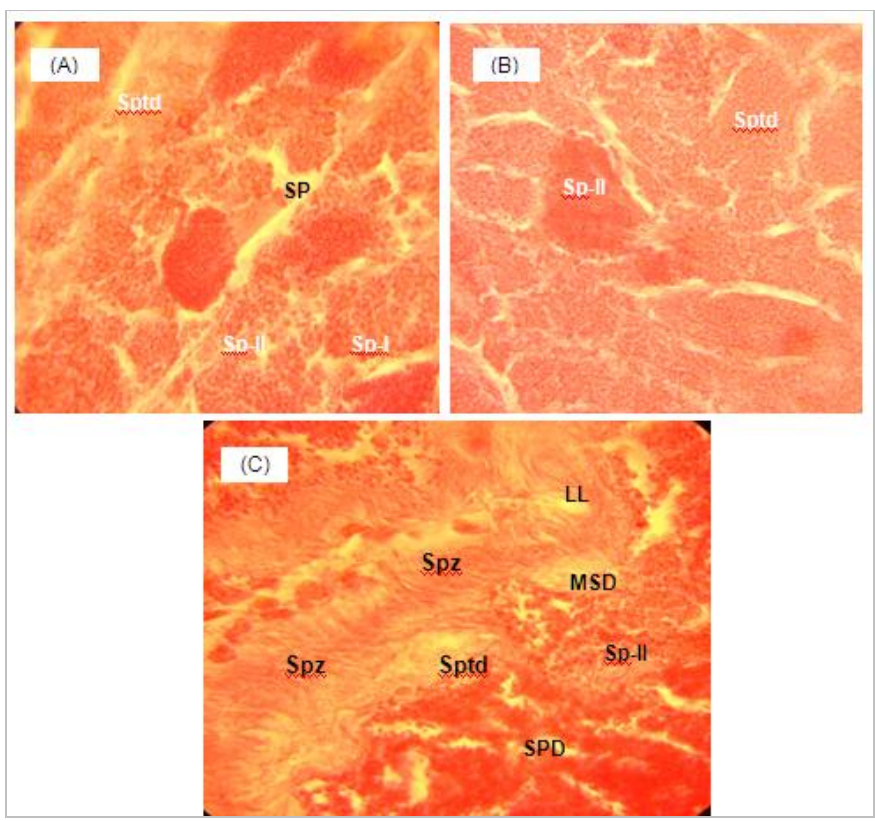

Fig. 8: Cross section showing the lobular and tubular arrangements of the testis of an adult specimen at stage IV. (A) Observation of testes under higher magnification showing three tubules arranged side by side ( $\times 1000)$. ( $H \& E$ ). (B) Observation of the inside of the tubule under higher magnification $(\times 1000)$. ( $\mathrm{H} \& \mathrm{E})$. (C) Observation of central medulla of a running male under higher magnification $(\times$ 1000). (H \& E). LL = lobular lumina; MSD = main sperm duct; SPD = sperm duct; Sp-I = primary spermatocytes; Sp-II $=$ secondary spermatocytes; Sptd $=$ spermatids; $\mathrm{Spz}=$ spermatozoa.

\section{The spent stage V (Fig. 9)}

Blood vessels on the ventral side of testes were conspicuous. Testes were flaccid, with milt still present therein. They were whitish in colour, yet milk-like. Such colouring is typical of this stage (Fig. 9A). With a pressing to the abdomen, bloody milt sometimes came out. Photomicrograph shows that the lobules and tubules are separate from each other by spaces which are an extension of the sperm duct (Fig. 9B). Almost all phases of the spermatogenesis can be seen in a single tubule.

The stage $\mathrm{V}$ can show remarkable peculiarities depending on two cases. First, at the end of the reproduction season, as the spermatogenesis process reaches its end, a few residual spermatozoa are observed throughout the testis, in shrunken lobules and tubules. Second, if reproduction still goes on, as is the case in the current study (Fig. 9B), the lobules and tubules contain all types of gametes, namely spermatocytes, spermatids and spermatozoa. 


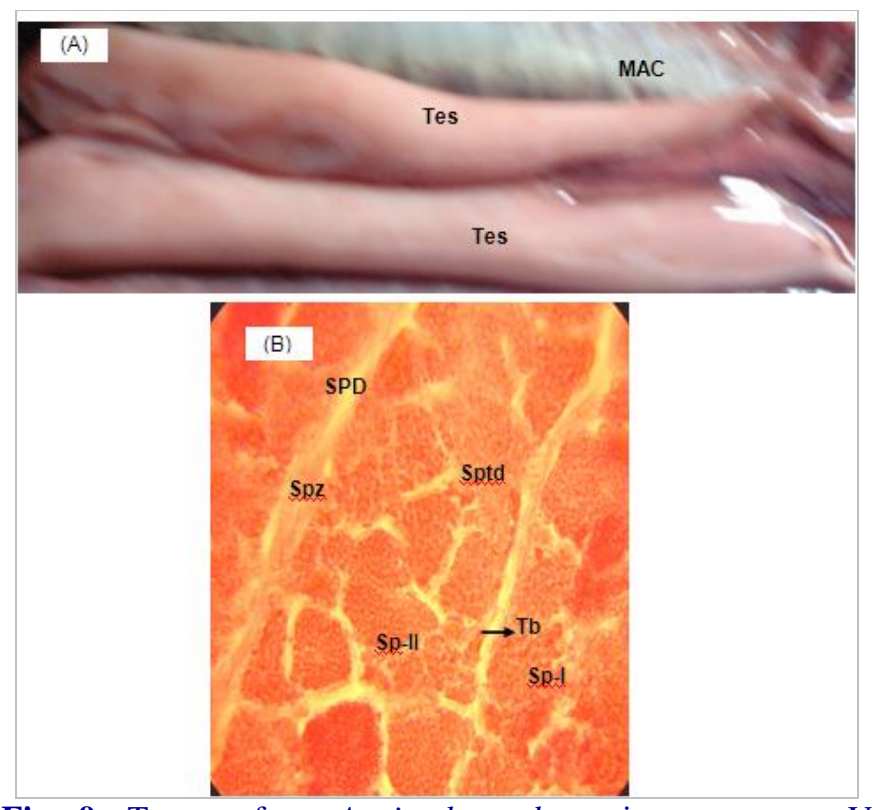

Fig. 9: Testes of an Auxis thazard specimen at stage V (spent). (A) Overall appearance of testes at spent stage. (B) Observation of testes under higher magnification showing three tubules of a spent specimen $(\times 1000)$. $(\mathrm{H} \& \mathrm{E})$. MAC $=$ muscles of abdominal cavity; SPD = sperm duct; Sp-I = primary spermatocytes; $\mathrm{Sp}$-II $=$ secondary spermatocytes; Sptd $=$ spermatids $; \mathrm{Spz}=$ spermatozoa $; \mathrm{Tb}=$ tubules .
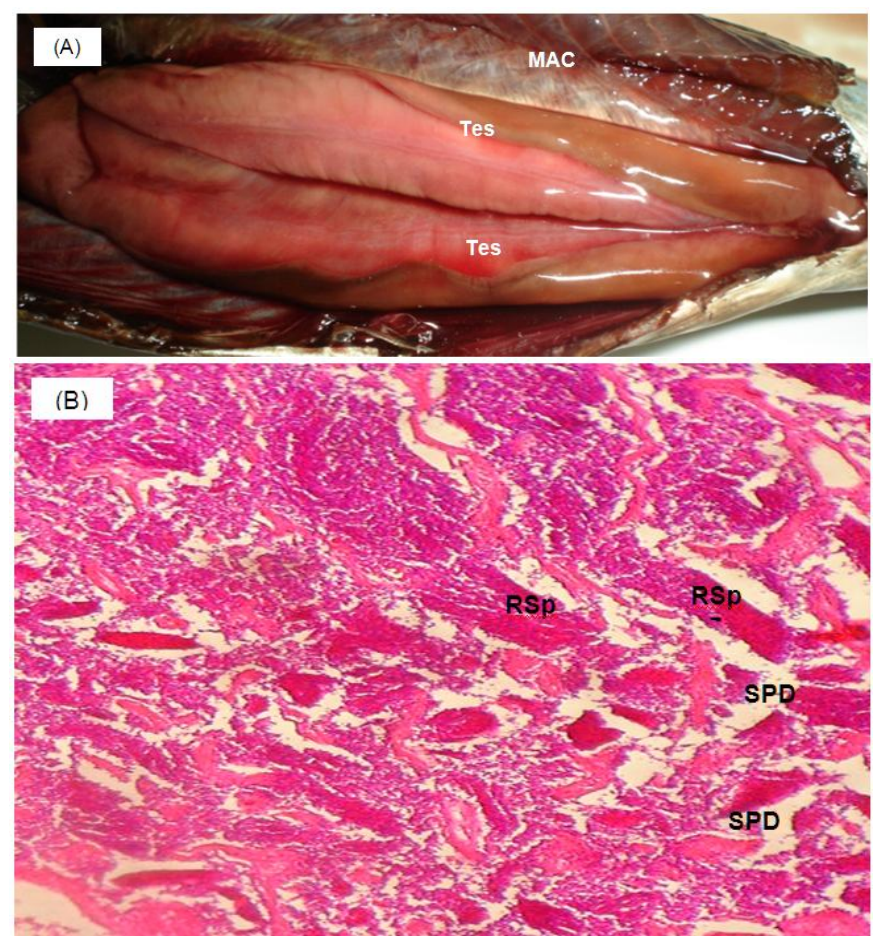

Fig. 10: Testes of an Auxis thazard specimen at resting stage. (A) Overall appearance of testes of a specimen at resting stage. (B) Cross section of the testis of a resting male $(\times 200)$. $(\mathrm{H} \& \mathrm{E}) . \mathrm{MAC}=$ muscles of abdominal cavity; SPD $=$ sperm duct; $\mathrm{RSpz}=$ residual spermatozoa; Tes $=$ testes.

\section{The resting stage VI (Fig. 10)}

Testes were no more whitish on the dorsal side, yet blood vessels still visible on the ventral side made it possible to observe a combination of whitish and pinkish colourings on this later side. Testes were lighter and shrunken (Fig. 10A). Though testes were shrunken in size, they got firmer than in spent condition. There was no bloody milt flowing out when pressing the abdomen. Cross section of testes showed disordered testes as a result of the damage to structural tissue (Fig. 10B). The lobules and tubules are relatively empty of germ cells. However, we can observe some residual spermatozoa.

\section{Discussion}

The specimens of frigate tuna that were captured with the nets used by the small-scale fishery ranged in size from juveniles to adults. Access to this stock was facilitated by the fact that these small tuna are neritic, though oceanic (Collette and Nauen, 1983; Valeiras and Abad, 2010). Sizes at which these specimens were caught are the ones usually encountered in the catches made through surface fishing gears, generally $25 \mathrm{~cm} \mathrm{FL}$ as regards frigate tuna (Collette and Nauen, 1983).

In the current study, we identified two regions in the testis, due to its being constituted by two parts, namely the dorsal and the ventral sides. Depending on the maturity stages of the fish, each region gets countershaded. In immature fish, the cortex is much more shaded than the medulla, probably because it is much thicker. As the fish mature, shade in both sides becomes inverted. With the medulla being progressively filled with germ cells at different division stages, the medulla becomes thicker, thus more shaded, and the cortex lightens because of its getting thinner. Ratty et al. (1990) reported morphological changes in testes related to the thickness of the main duct in a tuna species other than frigate tuna. According to these authors, in the immature testis, the main sperm duct is thin-walled and highly convolute. In the mature testis, however, the main duct has thicker walls, and is less convolute (Ratty et al., 1990). Just as in South Pacific Albacore tuna Thunnus alalunga (Ratty et al., 1990), so the main duct is present in immature frigate tuna testis, even though no spermatozoa are observed therein. As frigate tuna mature, the main sperm duct gets located near the center of the testis, along with the tubules convergence zone (TCZ) where a branching system of tubules radiates toward the testicular periphery. According to Meister 
and Pashuk (2005), the main testicular ducts of each testis join together to form the common sperm duct, through which the male gametes are transported from the testes to outside the body. In many other teleosts, however, the main duct is located along the dorsal surface of the testis and may not be present in immature stages of the testis (Grier et al., 1980). Which make them different from South Pacific Albacore tuna (Ratty et al., 1990) and from frigate tuna, at least regarding the testicular peculiarities. Yet frigate tuna, like the majority of teleosts, have the same testicular cellular development. For that reason, we classified the germ cells into the following phases of developmental order: spermatogonia, primary spermatocytes, secondary spermatocytes, spermatids, and spermatozoa. Additionally, the lobular-type cellular arrangement we observed in the frigate tuna testis is typical of most teleosts (See Billard et al., 1982). Still, observation of germ cells, which appeared as if dots-like, is not a characteristic of our study. That seems to be common in male fishes, regardless of species, as shown by many other studies on Thunnus albacares (Albaret, 1976), Heterobranchus longifilis (Otémé, 2001), Thunnus thynnus (Rooker et al., 2007), Auchenoglanis occidentalis (Shinkafi et al., 2011), and in which the slides were observed under a light microscope. For such reasons, no spermatozoa (morphologically subdivided into head, neck piece, short midpiece, and tail) were observed in the current study, due to non-utilization of an electron microscope that enables observation of spermatozoa in their entirety.

\section{Conflict of interest statement}

Authors declare that they have no conflict of interest.

\section{Acknowledgement}

The first author wishes to thank the Centre de Recherches Océanologiques (CRO) and the French Institute for Research Development (IRD) for placing infrastructure at his disposal. All authors are thankful to anonymous reviewers for their helpful suggestions.

\section{References}

Albaret, J.J., 1976. Reproduction de l'albacore (Thunnus albacares, Bonnaterre, 1788) dans le golfe de Guinée. Thèse de Doctorat $3^{\text {iè }}$ Cycle, Biologie Animale - Zoologie Expérimentale, Université Paris 7, 1976/11/10.
Bahou, L., 2013. Exploitation par la pêche artisanale maritime, Biologie de la reproduction et Régime alimentaire de deux thonidés mineurs: Auxis thazard (Lacepède, 1800) et Euthynnus alletteratus (Rafinesque, 1810) du plateau continental ivoirien. Thèse de Doctorat, Université Félix HouphouëtBoigny de Cocody, Abidjan, Côte d'Ivoire.

Bahou, L., Koné, T., N'Douba, V., N'Guessan, K.J., Kouamélan, E.P., Gooré, B.G., 2007. Food composition and feeding habits of little tunny (Euthynnus alletteratus) in continental shelf waters of Côte d'Ivoire (West Africa). ICES J. Mar. Sci. 34, 244-252.

Bard, F.X., N'Goran, Y.N., Hervé, A., Amon-Kothias, J.B., 2002. La pêcherie piroguière au filet maillant de grands pélagiques au large d'Abidjan (Côte d'Ivoire). Arch. Scient. Centre Recher. Océanol. Abidjan. 17, 13-35.

Billard, F., Fostier, A., Weil, C., Breton, B., 1982. Endocrine control of spermatogenesis in teleost fish. Can. J. Fish. Aquat. Sci. 39, 65-79.

Chur, V.N., 1972. Some biological characteristics of little tuna (Euthynnus alletteratus Rafinesque, 1810) in the Eastern part of Tropical Atlantic. Collective Vol. Scient. Pap. ICCAT, SCRS / 72 / 51, 1, 489500.

Collette, B.B., Nauen, C.E., 1983. FAO Species Catalogue. 2nd Edn. Scombrids of the world. An annotated and illustrated catalogue of tunas, mackerels, bonitos and related species known to date. FAO Fish. Synop. (125p.).

Diouf, T., 1980. Premières données relatives à l'exploitation et à la biologie de quelques "petits thonidés et espèces voisines »: Euthynnus, Sarda, Scomberomorus au Sénégal. Collective Vol. Scient. Pap. ICCAT, SCRS / 80 / 52.15 (2), 327-336.

FAO., 2012. FAO Fisheries and Aquaculture. Tuna and tuna-like species group. Available at http://www.fao.org./fishery/topic/16082/en

Grier, H.J., Linton, J.R., Leatherland, J.F., De Vlaming, V.L., 1980. Structural evidence for two different testicular types in teleost fishes. Am. J. Anat. 159, 331-345.

Jiménez-Prado, P.R., Béarez, P., 2004. Pecos Marinos del Ecuador continental. Tomo $2^{\text {nd }}$ Edn. Guía de Especies / Marine fishes of continental Ecuador. Volume 2. Species Guide. Sociedad para la Investigación y Momtoreo de la Biodiversidad Ecuatoriana / Nazca / Instituto Franés de Etudios Andinos, Quito.

Martoja, R., Martoja-Pierson, M., 1967. Initiation aux 
techniques d'histologie animale. Masson, Paris.

Meister, H.S., Pashuk, O., 2005. Male reproductive classification in gonochoristic marine fishes. In: Agenda for 2005 Gonadal Histology Workshop, July 12-13 FWC, St Petersburg, Florida. pp.36 -40 .

Otémé, Z.J., 2001. Contribution à l'étude de la Physiologie de la reproduction du Silure Heterobranchus longifilis Valenciennes, 1840 (Clariidae) : gamétogenèses naturelle et induction. Thèse de Doctorat $3^{\text {me }}$ Cycle. Spécialité Biologie et Physiologie Animales - Option Pisciculture. Université de Cocody, Abidjan, Côte d'Ivoire.

Ratty, F.J., Laurs, R.M., Kelly, R.M., 1990. Gonad morphology, histology, and spermatogenesis in South Pacific Albacore tuna Thunnus alalunga (Scombridae). Fish Bull. (U.S.). 88, 207-216.

Rooker, J.R., Alvarado-Bremer, J.R., Block, B.A.,
Dewar, H., De Mekrio, G., Correro, A., Krauss, R.T., Prince, E.D., Rodriguez-Marío, E., Secor, D.H., 2007. Life history and stock structure of Atlantic Bluefin tuna (Thunnus thynnus). Rev. Fish. Sci. 15, 265-310.

Shinkafi, B.A., Ipinjolu, J.K., Hassan, W.A., 2011. Gonad Maturation Stages of Auchenoglanis occidentalis (Valenciennes 1840) in River Rima, North-Western Nigeria. J. Fish Aquat. Sci. 6(3), 236-246.

Valeiras, L., Abad, E., 2010. Description de l'auxide (FRI)/Biologie de la reproduction de Euthynnus alletteratus, in Mannuel ICCAT, Commission Internationale pour la Conservation des Thonidés de l'Atlantique, 1ère Édition (Janvier 2010), Chapitre 2.1.10.3. Description de l'auxide, pp 226-234./ Chapitre 2.1.10.5. Thonine. Dernière mise à jour: 4 Septembre 2006. pp.244-251.

\section{How to cite this article:}

Bahou, L., d'Almeida, M.-A., Atsé Boua, C., Koné, T., 2017. Histology and spermatogenesis in frigate tuna Auxis thazard (Lacepède, 1800) caught in continental shelf waters of Côte d'Ivoire. Int. J. Curr. Res. Biosci. Plant Biol. 4(6), 24-32. doi: https://doi.org/10.20546/ijcrbp.2017.406.003 